Winter 1-30-2020

\title{
Sustainable Stock Market and Sustainability Reporting Propensity of the Public Sector: Mediating Role of the Private Sector
}

\author{
Ali Uyar \\ Cemil Kuzey \\ Murray State University, ckuzey@murraystate.edu \\ Merve Kilic
}

Follow this and additional works at: https://digitalcommons.murraystate.edu/faculty

Part of the Business Commons

\section{Recommended Citation}

This is an Accepted Manuscript of an article published by Taylor \& Francis in International Journal of Public Administration on January 30, 2020 available online: https://doi.org/10.1080/ 01900692.2020 .1719512

This Journal Article is brought to you for free and open access by Murray State's Digital Commons. It has been accepted for inclusion in Faculty \& Staff Research and Creative Activity by an authorized administrator of Murray State's Digital Commons. For more information, please contact msu.digitalcommons@murraystate.edu. 


\title{
Sustainable stock market and sustainability reporting propensity of the public sector: the mediating role of the private sector
}

\begin{abstract}
The objective of this article is to investigate the mediating role of the private sector between sustainable stock markets (i.e., the existence of a sustainability index) and the sustainability reporting level of the public sector through spillover theory. The sample of the study consists of 115 country records for 2015 and 2016 . The results confirm that the private sector mediates the association between sustainable stock markets and the sustainability reporting level of the public sector. Hence, establishing sustainability indices in stock markets first helps the private sector achieve a higher level of transparency, and then they indirectly help public organizations be more transparent and accountable to their stakeholders.
\end{abstract}

Keywords: Public sector, Private sector, Sustainability report, Stock market, Sustainability index, Spillover theory

\section{Introduction}

As many of the sustainability reporting tools and techniques originated from the private sector (Guthrie, Ball, \& Farneti, 2010), most previous studies primarily put private companies under the scope. So far, much has been written on the drivers of sustainability reporting practices in the private sector ${ }^{1}$. However, despite the increasing importance of sustainability reporting in the public sector, previous research paid little attention to public sector sustainability reporting practices (Bellringer, Ball, \& Craig, 2011; Alcaraz-Quiles, Navarro-Galera, \& Ortiz-Rodríguez, 2015; Domingues, Lozano, Ceulemans, \& Ramos, 2017). Guthrie et al. (2010) asserted that researchers have largely overlooked the public sector in social and environmental studies, although some notable exceptions exist (Burritt \& Welch, 1997a; Burritt \& Welch, 1997b; Guthrie \& Farneti, 
2008; Dumay, Guthrie, \& Farneti, 2010; Adams, Muir, \& Hoque, 2014). However, it is promising that there is a growing interest among public sector organizations in disseminating sustainability reports on the organizational web sites and the disclosure database of Global Reporting Initiative $(\mathrm{GRI})^{2}$.

Many studies on public sector sustainability reporting have concentrated on a single country (Alcaraz-Quiles et al., 2015; Greco, Sciulli, \& D’Onza, 2015; Yadava \& Sinha, 2016)³. With few exceptions (Greiling \& Grüb, 2014; Navarro Galera, de los Ríos Berjillos, Ruiz Lozano, \& Tirado Valencia, 2014; Greiling, Traxler, \& Stötzer, 2015; Domingues et al., 2017; Uyar, Kuzey, \& Kilic $2019)^{4}$, no previous study has used a cross-country data set to examine sustainability reporting adoption by the public sector organizations internationally. There is a growing recognition that organizations operate in wider ecosystems instead of as separate entities (Dumay et al., 2010). Therefore, other macro-level (i.e., external) factors beyond organizational-level (i.e., internal) factors may push organizations to issue sustainability reports both in public and private sectors. Thus, this study utilizes a set of macro-level indicators to explore sustainability reporting practices of the public sector organizations.

The public sector might be different from the private sector in several aspects. First, the public sector is not driven purely by economic returns but by social values incorporated in the formation of public policy and delivery of public services (Farneti \& Guthrie, 2009). Second, in comparison with private sector organizations, public sector organizations have a greater number of stakeholders (i.e., taxpayers, public service users, voters, and employees) that have a legitimate interest in the disclosure of financial and non-financial information (Greiling \& Grüb, 2014). Third, in the public sector, even one particular stakeholder group can have quite different and sometimes conflicting information needs (Greiling et al., 2015). For example, the information 
needs of citizens would differ in their role as consumers of public services from in their role as taxpayers (Greiling et al., 2015). Further, the outcomes of sustainability projects of the public sector cannot be easily quantified, and the timescales for delivery are long (Lewis, 2008). This condition makes public sector organizations more long-term oriented to realize their sustainability targets in comparison with private sector organizations (Koppenjan \& Enserink, 2009). Additionally, whereas sustainability reporting provides a significant competitive advantage to private sector organizations, no competitive advantage can be gained from the sustainability reporting in the public sector because of the non-competitive nature of the operations of public sector organizations (Adams et al., 2014).

As the public sector lags behind the private sector in the process of sustainability reporting (Domingues et al., 2017; Uyar et al., 2019), public sector organizations can learn from the private sector's knowledge and experience in sustainability reporting practices (Dumay et al., 2010). Supporting this perspective, Grossi and Steccolini (2015) argued the adaptability of the private sector's applications to the public sector. Besides, in the sustainable development of the countries, the stock markets with sustainability indices play a significant role in the adoption of sustainability practices and reporting across organizations (López, Garcia, \& Rodriguez, 2007). While these indices have a direct influence on motivating and guiding private sector companies (Orsato, Garcia, Mendes-Da-Silva, Simonetti, \& Monzoni, 2015), they are unlikely to have a direct effect on the public sector. Therefore, this study posits that the sustainability indices in the stock markets of the nations are likely to influence the public sector's sustainability reporting propensity through the mediation of the private sector. In other words, the study hypothesizes the existence of a knowledge spillover from the private sector over the public sector in the sustainability reporting practices initiated by the sustainable stock markets ${ }^{5}$ (i.e., market-level spillover). Although sector- 
level and geographical spillover effects in the sustainability reporting domain were tested and verified before (Uyar et al., 2019), the market-level spillover approach is unprecedented and untested and responds to the call of Uyar et al. (2019) regarding the applicability of spillover theory in other domains. It is hoped that this investigation based on three main actors in the nations (i.e., stock market, private sector, and public sector) provides useful insights into achieving sustainable development goals of all organizations and the whole society.

The remaining sections of the article proceed as follows. The next section reviews the literature, and subsequently, the third section establishes the theoretical foundation and develops the hypotheses. The fourth section outlines the research methodology, which is followed by the findings. Finally, conclusions are drawn along with implications, limitations, and future research avenues.

\section{Literature review}

In the literature, sustainability reporting within the public sector is usually examined on the basis of arguments drawing on legitimacy theory (Dumay et al., 2010; Lodhia, Jacobs, \& Park, 2012; Greiling \& Grüb, 2014; Navarro Galera et al., 2014; Alcaraz-Quiles et al., 2015), stakeholder theory (Greiling \& Grüb, 2014; Navarro Galera et al., 2014; Alcaraz-Quiles et al., 2015; Greco et al., 2015; Guenther, Guenther, Schiemann, \& Weber, 2016), and institutional theory (Joseph \& Taplin, 2012; Greiling et al., 2015). Although these frequently used theories provide important insights into understanding organizations' sustainability practices, there is a need to adopt some other theories to uncover the relationships among organizations and different parts of the societies. Therefore, this study adopts the theories of knowledge spillover (Liu, Lu, Filatotchev, Buck, \& Wright, 2010; Acs, Brooksbank, O’Gorman, Pickernell, \& Terjesen, 2012; Pittz \& White, 2016; Wang \& Wu, 2016) and behavioral spillover (Thøgersen, 1999; Thøgersen \& Crompton, 2009; 
Thøgersen, 2012; Nash et al., 2017) to understand the drivers of sustainability reporting adoption by public sector organizations. Knowledge spillover refers to the dissemination of new perspectives and knowledge from one party to other parties (i.e., across organizations) (Pittz \& White, 2016). Behavioral spillover refers to the influence of the adoption of a particular behavior on the likelihood of adoption of other related behaviors (Thøgersen \& Crompton, 2009).

In general, the spillover effect is a consequence of an increasingly interdependent society and nested systems, including cultural, economic, and political. Indeed, spillover effects have been tested by a broader range of disciplines, including education (Nilsson, \& Bergquist, \& Schultz, 2017), economics (Ertur, Le Gallo, \& Baumont, 2006; Ferreira \& Gama, 2007; Shi, 2013), management (Reid \& Toffel, 2009; Liu et al., 2010), international business (Acs et al., 2012; Wang \& Wu, 2016), marketing (Sirgy, 2008; Assaf, Josiassen, Ahn, \& Mattila, 2017), finance (Wang \& Liu, 2016), and accounting (Kang, 2008; Beatty, Liao, \& Yu, 2013; Brown, Tian, \& Tucker, 2018). Nevertheless, in contrast to the growing body of literature on spillover effects, to date, only Uyar et al. (2019) has tested this phenomenon in the voluntary corporate reporting domain by investigating sectoral and geographical spillover. Therefore, the present paper is an initial attempt to examine the market-level spillover effect on the public sector sustainability reporting domain.

In a globalized world, spillover effects are becoming more and more important (Shi, 2013). They may occur from changes in knowledge and experience, awareness, availability of infrastructure and resources, technological advances, and policy change (Nash et al., 2017). Spillover effects are mainly divided into two: positive and negative (Kang, 2008; Thøgersen \& Crompton, 2009; Liu et al., 2010; Shi, 2013; Nilsson et al., 2017). Positive spillover effects occur when the adoption of a particular behavior leads to the adoption of other related behaviors (Thøgersen \& Crompton, 2009). For example, small pro-environmental behaviors can spillover 
into the adoption of more ambitious and environmentally significant behaviors (Thøgersen \& Crompton, 2009). Conversely, negative spillover effects occur when the adoption of a particular behavior decreases the likelihood of adoption of other related behaviors (Nash et al., 2017). In propositions of this study, a spillover effect refers to a positive spillover effect. The basic premise

in positive spillover effects within the corporate reporting domain is that the adoption of a sustainability reporting practice by an organization would increase the likelihood of adoption of this practice by other organizations.

\section{Theoretical framework and development of hypothesis}

Stock markets are the mechanisms in which large and small investors meet and trade shares of corporations in the hopes of obtaining a satisfactory return. Empirical evidence shows that wellfunctioning stock markets promote long-term economic growth (Levine \& Zervos, 1998). To attain market efficiency and to protect the rights of investors, establishing institutional regulations that govern transparency and accountability practices among corporations is important. Therefore, the listed companies on stock exchanges are subject to both mandatory and voluntary information disclosure requirements. Within the boundary of voluntary disclosures, sustainability reporting serves a significant purpose in the transparency and accountability of the firms.

The market-level spillover effect refers to the role of the stock market in the dissemination of information over the public sector through a market mechanism in a country. Empirical evidence shows that the stock market has a significant effect on the information disclosure of companies (Cooke, 1992; Meek, Roberts, \& Gray, 1995; Hackston \& Milne, 1996). For example, in one of the earliest studies, Singhvi and Desai (1971) found that listing status, whether a company's shares are traded on an organized stock exchange or not, affects information disclosure. Cooke (1992), Hackston and Milne (1996), and Chiu and Wang (2015) also proved that cross-listed corporations 
disseminate more information than their counterparts listed only in one stock market such as the local one. Many recent studies provided evidence on the positive role of stock markets in various types of information disclosures, including environmental and corporate social responsibility disclosures (Oliveira, Rodrigues, \& Craig, 2011; Branco, Delgado, Gomes, \& Eugénio, 2014; Chiu \& Wang, 2015; Braam, Uit De Weerd, Hauck, \& Huijbregts, 2016; Menassa \& Brodhäcker, 2017; Petera \& Wagner, 2017; Kılıç \& Kuzey, 2018).

Sustainability-related reporting regulations for listed companies affect the corporate behavior not only of the targeted companies (i.e., listed ones) but also of other companies (i.e., non-listed ones) and organizations within the same institutional field (i.e., state, country) because they are likely to view themselves as possible targets of future regulation (Reid \& Toffel, 2009). The indirect effect of regulations on corporate behavior beyond the targeted companies is referred to as the spillover effect (Brown et al., 2018). This spillover effect leads to an indirect benefit by diffusing the effect of regulatory enforcement activity on a particular group of companies among many others (Reid \& Toffel, 2009). For example, Brown et al. (2018) found that the Securities and Exchange Commission comment letters on qualitative corporate disclosures also affected the disclosures of companies not receiving any comment letter in the subsequent year.

Based on the above discussion, this study posits that the presence of a sustainability index in a stock market can enhance the sustainability orientation of all companies and organizations in a country beyond the targeted (i.e., listed) ones. In other words, sustainability reporting practices spread from listed companies to non-listed ones and public organizations. The trend of developing sustainability indices was initiated by Kinder, Lydenberg, Domini, and Co. with the launch of the Domini 400 Social Index in the 1990s (Orsato et al., 2015). Stock exchanges launch such indices to promote companies to act socially, to be environmentally responsible, and to disclose 
information on sustainability initiatives (de Souza Cunha \& Samanez, 2013). Although Ioannou and Serafeim (2012) could not prove the significant influence of sustainability index on sustainability performance of companies in their cross-country study, two recent studies verified the significant positive role of the sustainability index in the sustainability disclosure of firms (Michelon \& Parbonetti, 2012; Kılıç \& Kuzey, 2018). Eventually, this study predicts that the presence of a sustainability index in a stock market will increase the level of sustainability reporting issued by public sector organizations with the mediation of the private sector. Thus, the following hypotheses are formulated:

Hypothesis 1: The sustainability orientation of a stock market (i.e., the existence of sustainability index) increases the number of all sustainability reports (i.e., with or without a specific reference to GRI frameworks) disseminated by the public sector through the mediation of the private sector.

Hypothesis 2: The sustainability orientation of a stock market increases the number of GRIbased sustainability reports (i.e., with a specific reference to GRI frameworks) disseminated by the public sector through the mediation of the private sector.

This study's purpose of establishing these two similar hypotheses with a slight difference is to verify whether test results confirm both all reports' (i.e. including GRI-based and non-GRI-based) results as well as only GRI-based reports' results. Thus, the reader should consider the second hypothesis as the robustness of the first hypothesis.

\section{Research methodology}

The research methodology of this research paper includes descriptive statistics, regression analysis based on Ordinary Least Square approach, and the mediation analysis. The summary of the variables using mean, standard deviation, ranges, and the Pearson's Correlation analysis. In 
addition, the OLS test the direct association of SustIndex and PrivSecReport/GRI with PubSecReport/GRI before the mediation analysis. Finally, the mediation analysis test the association between SustIndex and PubSecReport/GRI through PrivSecReport/GRI.

\section{Sample and data sources}

The initial sample of this study was determined by selecting countries for which stock market data were available in the World Bank Database (WorldBank, 2017) for the years 2015 and 2016. As the sustainable stock market is the independent variable of the study, the sample of the study had to consist of all stock markets with/without sustainability index around the world. This constraint yielded 65 countries satisfying this condition, accordingly, 130 country-year observations were obtained for the two years. However, because of listwise missing data, 58 countries' records were available in 2015 while 57 countries' records were available in 2016 which makes 115 countryrecords in total for the two years. All data for the study were collected from four sources. First, the stock markets with a sustainability index were identified from the Sustainable Stock Exchanges Initiative (SSE, 2017). The SSE, which was initiated in 2009 by the United Nations (UN) Secretary-General, is a UN Partnership Program of the UN Environment Program Finance Initiative, the UN Conference on Trade and Development, the Principles for Responsible Investment, and the UN Global Compact (SSE, 2019). Specifically, the inclusion of the sustainability index is due to its role in the development of sustainable markets and societies (SSE, 2017). The SSE is an initiative aiming to promote capital allocation in the stock markets not only based on financial performance but also social and environmental performance (Chabrak, 2018). Sustainability indices typically use three main indicators, namely, social, environmental, and corporate governance, to assess companies' related performances (de Souza Cunha and Samanez, 
2013). Following previous studies (Michelon \& Parbonetti, 2012; Ioannou \& Serafeim, 2012; Kılıç \& Kuzey, 2018), the existence of a sustainability index (i.e., SustIndex) was coded on a yes/no (i.e., 1/0) basis. Second, the number of all sustainability reports as well as GRI-based sustainability reports for the public and private sector across countries were obtained from a unique GRI Sustainability Disclosure Database (GRI SDD, 2017). This database is a unique and publicly available source for sustainability reports issued by the private and public sector, and it enables organizations around the world upload their sustainability reports for the use of stakeholders. Therefore, it helps researchers to identify the number of sustainability reports based on sector, country, and the year. The GRI sustainability report database was utilized by prior studies as a data source as well (Fernandez-Feijoo, Romero, \& Ruiz, 2014; K1lı̧, Uyar, \& and Karaman, 2019; Uyar et al., 2019). Third, the following control variables were derived from the database of the World Bank (WorldBank, 2017); exports as a percentage of the GDP to control for trade openness (Kılıç et al., 2019), GDP to control for the economic development (Kılıç et al., 2019), rule of law to account for legislative differences among nations (de Villiers \& Marques, 2016), the percentage of general government expenditure relative to GDP to control for the public sector size (Uyar et al., 2019), the population to account for country size (Alcaraz-Quiles et al., 2015), and market capitalization of the stock markets as a percentage of the GDP (Uyar et al., 2019). Fourth, the data for another control variable, namely financing through the local equity market, were obtained from the Global Competitiveness Index (GCI) issued by the World Economic Forum (WEF, 2016). The GCI ranks countries in terms of economic and institutional development under 12 pillars. One of those pillars is Financial Market Development under which financing through the local equity market is one of the indicators (WEF, 2016). This individual indicator assesses to what extent corporations raise capital by issuing bonds and/or shares on the stock market. The GCI has been 
utilized as a source of variables in prior studies (Ekici et al., 2016; Pérez-Moreno et al., 2016). Table 1 lists all the variables used in the study along with their measurements and sources, and Figure 1 illustrates the theoretical structure highlighting the relationships among constructs.

[Table 1 here]

[Figure 1 here]

\section{Descriptive statistics}

The descriptive statistics of the variables are provided in Table 2. They show that the PubSecReport ranging between 0 and 84 with a mean value of $9.40 \pm 18.57$ while PrivSecReport ranging between 0 and 3778 with an average of $517.55 \pm 728.26$. These values help to compare public and private sectors' sustainability reporting frequency respectively. Besides, the mean PubSecGRI is $7.43 \pm 15.85$ and the mean PrivSecGRI is $406.51 \pm 550.64$ which shows that GRIbased sustainability reporting frequency of two sectors. It is obvious that the GRI framework is adopted in the majority of the reports published by both private and public sectors. While average ExportRatio is $51.65 \%$, MarketCapt is $79.99 \%$, GovernExp is $16.41 \%$. Moreover, while average RuleLaw (0.59) indicates countries' current level of rule of law quality, and the average of EquitMarkt (4.19) shows the degree of financing through the equity market in countries. Finally, there are $54(47 \%)$ country-year records with the existence of sustainability index while 61 (53\%) country-year records do not include sustainability index.

[Table 2 here]

\section{Correlation analysis}

The bivariate linear relationships between the variables using Pearson's correlations analysis are provided in Table 3. The results show that PrivSecReport $(\mathrm{r}=50.4 \%, \mathrm{p}<1 \%)$, SustIndex $(\mathrm{r}=$ $18.9 \%, \mathrm{p}<5 \%)$, GDP $(\mathrm{r}=43.0 \%, \mathrm{p}<1 \%)$, RuleLaw $(\mathrm{r}=37.5 \%, \mathrm{p}<1 \%)$, and EquitMarkt $(\mathrm{r}=$ 18.6\%, $\mathrm{p}<5 \%$ ) have significant positive bivariate linear relationship with PubSecReport. In 
addition, PrivSecGRI $(r=50.6 \%, p<1 \%)$, SustIndex $(r=19.4 \%, p<5 \%), \operatorname{GDP}(r=39.0 \%, p<1 \%)$, and RuleLaw $(\mathrm{r}=32.2 \%, \mathrm{p}<1 \%)$ have significant positive bivariate linear association with PubSecGRI.

[Table 3 here]

\section{Results}

\section{Regression analysis}

The multiple regression analysis which is an extension of simple linear regression can be empoted to predict the value of a dependent variable based on the two or more predictor variables known as independent variables (Draper \& Smith, 1998). Regression analysis includes ordinary least squares (OLS) and weighted least squares approaches in order to estimate the unknown parameters in a linear regression model (See Eq 1). The OLS methodology minimize the sum of the squares of the differences between the actual dependent variable values and the predicted values by the linear function in the provided data set in order to estimate the coefficients, $\beta_{i}$, (Wooldridge, 2013). In addition to the prediction, the regression analysis can also be utilized for performing hypothesis tests as well as constructing confidence intervals (Davidson \& MacKinnon, 2004).

$\mathrm{Y}=\beta_{0}+\beta_{1} \mathrm{X} 1+\beta_{2} \mathrm{X} 2+\ldots+\beta_{k} \mathrm{Xk}+\varepsilon$

where y shows the dependent variables and $\mathrm{Xi}(\mathrm{i}=1,2, \ldots, \mathrm{k})$ indicates the independent variables. Initially, multiple regression analysis with Ordinary Least Square method was used in order to investigate the association between SustIndex and PubSecReport/PubSecGRI, between SustIndex and PrivSecReport/PrivSecGRI together with the control variables (Table 4). Following the investigation of the direct associations between the stated independent and the dependent variables, the indirect associations using mediation analysis to test the aforementioned hypotheses which 
tests the association between SustIndex and PubSecReport/GRI through PrivSecReport/GRI are investigated.

Accordingly, there is a significant positive relationship between SustIndex and PrivSecReport ( $\beta$ $=252.8, p<.05)$, and between SustIndex and PrivSecGRI $(\beta=213.9, p<.01)$ while there is no significant association between SustIndex and PubSecReport $(\beta=-3.49, p>.05)$, and between SustIndex and PubSecGRI $(\beta=-1.21, p>.05)$. Thus, the results indicate that the private sector tends to issue a greater number of sustainability reports in countries whose stock markets have already established a sustainability index. On the contrary, the existence of sustainability indices in the stock markets is not likely to have a significant association with the number of sustainability reports published by the public sector. Therefore, the next subsection tests the mediation effect of the private sector on the association between the sustainable stock markets and the sustainability reporting level of the public sector.

[Table 4 here]

\section{Mediation analysis}

Mediation is said to occur when a causal effect of some independent variable $\mathrm{X}$ on an outcome $\mathrm{Y}$ is explained by some intervening variable M (Shrout and Bolger, 2002). Baron and Kenny (1986) suggest three steps in analyzing the mediation which includes association between $\mathrm{X}$ and $\mathrm{Y}$, between $\mathrm{X}$ and $\mathrm{M}$, and between $\mathrm{X}+\mathrm{M}$ and $\mathrm{Y}$ based on regression analysis. The amount of mediation is represented by the indirect effect.

The proposed Hypotheses 1 and 2 are tested by using mediation analysis methodology with bootstrapping approach using PROCESS Macro (Hayes, 2013). Bias-Corrected bootstrapping which is an assumption-free methodology and that controls the Type- 1 errors is employed. The bias-corrected bootstrapping method is employed to estimate the interval of the indirect effects 
with 5,000 bootstrap resamples to obtain the $95 \%$ confidence interval (Preacher \& Hayes, 2008). Two models (i.e., all and GRI-based reports) with the same control variables are subject to the mediation analysis. In each hypothesis testing, the control variables are included in the model.

The mediation effect between independent and dependent variable via the mediator is considered to be statistically significant if the confidence interval of the indirect effect does not include zero (Preacher \& Hayes, 2008; MacKinnon, Lockwood, Hoffman, West, \& Sheets, 2002; Zhao, Lynch, \& Chen, 2010). Moreover, the direct effect is used to determine if the mediation is full or partial. Accordingly, the mediation is considered to be full-mediation if the direct effect is not statistically significant, namely the confidence interval includes zero while the mediation is considered to be partial-mediation if the direct effect is statistically significant, namely the confidence interval does not include zero.

The mediation analysis results are shown in Table 5 which includes the direct and indirect effects with lower and upper 95\% confidence limits. The proposed model is also visually illustrated in Figure 1. In the first model, SustIndex $(\mathrm{X})$ is the independent variable, PrivSecReport (M) is the mediator variable, and PubSecReport $(\mathrm{Y})$ is the dependent variable while ExportRatio, GDP, MarketCapt, EquitMarkt, RuleLaw, GovernExp, and Population are the control variables. The mediating effect of SustIndex on PubSecReport through PrivSecReport indicates that the indirect effect (2.344) is statistically significant since the lower and upper confidence limits do not include zero. The significant mediation is full since the direct effect (-5.83) is not statistically significant since the confidence limits include zero. The results reveal that PrivSecReport has a full mediation on the relationship between SustIndex and PubSecReport which confirm the validity of the first hypothesis. 
Similarly, in the second model, SustIndex (X) is the independent variable, PrivSecGRI (M) is the mediator variable, and PubSecGRI (Y) is the dependent variable while ExportRatio, GDP, MarketCapt, EquitMarkt, RuleLaw, GovernExp, and Population are the control variables. Based on the mediation analysis results, the indirect effect of SustIndex on PubSecGRI through PrivSecGRI reveals that the indirect effect (2.594) is statistically significant since the lower and upper confidence limits do not include zero which indicates a full mediation since the direct effect $(-3.801)$ is not statistically significant with the corresponding confidence limits including zero. Therefore, PrivSecGRI has a full mediation on the relationship between SustIndex and PubSecGRI which validates the second hypothesis. Hence, both models firmly support that the private sector fully mediates the association between the sustainable stock market and sustainability reporting level of the public sector. In other words, market-level spillover is realized over the public sector but with the help of the private sector. Finally, the results indicated that the proposed research hypothesis 1 and 2 are supported.

[Table 5 here]

\section{Discussions and conclusions}

This study, drawing on spillover theory, explores whether stock markets with sustainability indices drive public sector organizations to publish sustainability reports through the mediation of the private sector. The findings proved that while the sustainable stock market is significantly associated with the sustainability reporting level of the private sector but not with the sustainability reporting level of the public sector. Hence, the study confirms the positive role of sustainable stock markets in the sustainability reporting level of the private sector (Michelon \& Parbonetti, 2012; Orsato et al., 2015; Kılıç \& Kuzey, 2018). However, further analysis confirms that the private sector mediates the association between the sustainable stock market and the sustainability 
reporting level of the public sector. Hence, establishing sustainability indices in stock markets first helps the private sector achieve a higher level of transparency, and then they indirectly help public organizations be more transparent and accountable to their stakeholders. This indirect connection between market mechanism and sustainability reporting practices of the public sector can be explained with market-level spillover effect (Brown et al., 2018). Although the target of the sustainability index is to motivate publicly traded corporations in the stock market, it eventually affects organizations out of the stock market and results in unexpected positive consequences in the public domain (Reid \& Toffel, 2009).

The results provide implications for the stock markets, policy-makers, private companies, and public sector organizations. First, the stock markets by hosting a sustainability index do not solely influence investor behavior and the listed corporations on the stock exchanges (Orsato et al., 2015; SSE, 2017), but also public organizations. They serve the transformation of the whole society to a more sustainable environment (Vives, 2012). Considering this evidence, the stock markets which do not already establish a sustainability index is recommended to do so. Second, policy-makers might be proactive in undertaking the first step by initiating the establishment of these indices in the stock markets and subsequently can enact necessary regulations to ensure efficient functioning of this particular setup. These initiatives may ultimately serve the efficiency of the overall stock market since these indices require firms to disclose more non-financial information. The regulators can even take further steps to ensure the reliability of disclosed sustainability information by, for example, requiring internal and/or external assurance on sustainability reports. Otherwise, there might be a danger of losing the credibility of those sustainability indices if they do not reflect real environmental and social responsibility transformation (Umlas, 2008). Third, both the private and public sectors should take into account the private sector's mediating role in the knowledge 
spillover. This finding suggests more interaction between the two sides, namely the public and the private sectors (Uyar et al., 2019). Although the public sector is generally considered as the rulemaker and enforcer, and the private sector is perceived as the implementer, recent evidence draws these two parts of the society closer and invites more interaction. This study indicated that the public sector is also implementer by issuing sustainability reports to meet stakeholders' demands. In other words, the borders between these two sides are softened that opens the way to more interaction. It is hoped that this contact may even help the public sector better formulate future regulations regarding the sustainable development goals of the nations.

Due to growing pressures on public sector, it started to issue sustainability reports, albeit slow, following private sector (Kaur and Lodhia, 2019; Uyar et al., 2019). Compared to private sector, lower level of sustain ability engagement of the public sector is attributed to weak pressure of external stakeholders on the public organizations and more legitimacy need of private organizations (Alpenberg et al., 2019; Dobija et al., 2019). However, publishing a sustainability report might provide several advantages to public organizations such as monitoring sustainability performance, increasing transparency of the sector towards external and internal stakeholders, affecting organizational culture which may help aligning organizations towards more sustainability-oriented structures (Domingues et al., 2017). Sustainability reports may also help public sector's data management, organizational learning and communication processes (Niemann and Hoppe, 2018). Prior studies voiced the need of combined efforts of pubic and private sectors to develop solutions for ecological and societal problems (Brinkerhoff and Brinkerhoff, 2011). Although first private sector-initiated sustainability practices into its operations, public sector is expected to take leadership position in sustainability issues as regulator ${ }^{6}$ and implementer to boost private sector's commitment to environmental and social issues (Figueira et al., 2018). Despite 
public sector does not have shareholders like private sector against whom it is responsible for creating value, it has major stakeholders like public in general, civil organizations, and specifically taxpayers. Not to shake trust and morale of taxpayers (Torgler and Murphy, 2004), the public sector needs justify its expenditures which is closely related to consumption of resources since there are evidences. Besides, it is an important employer, service provider, and resource consumer which has significant impact on both environmental and social development ${ }^{7}$ (Kaur and Lodhia, 2019). It is hoped that proven spillover effect between private and public sector in this study provoke new thoughts for the private-public sector interaction and cooperation ${ }^{8}$ and for even some sort of partnership in developing joint sustainability projects (i.e., alleviating poverty, reducing fossil energy consumption, generating renewable energy, waste management etc.) for the public good.

The findings should be evaluated under the following limitations. First, the time period of the study covers the years 2015 and 2016. Thus, the findings might not be generalizable to before or after this period. Second, there is an inherent limitation with the usage of GRI database; there might be some sustainability reports published by the private and the public sector which are not uploaded to this system. Hence, those reports are out of the scope of this study. Furthermore, this study's way of approach might be adopted to some other domains (i.e., political spillover) such as whether political unions create a spillover among nations in sustainability reporting practices of the nations. 


\section{References}

Niemann, L., \& Hoppe, T. (2018). Sustainability reporting by local governments: a magic tool? Lessons on use and usefulness from European pioneers. Public management review, 20(1), 201-223.

Kaur, A., \& Lodhia, S. K. (2019). Sustainability accounting, accountability and reporting in the public sector. Meditari Accountancy Research, 27(4), 498-504.

Torgler, B., \& Murphy, K. (2004). Tax morale in Australia: What shapes it and has it changed over time Journal of Australian Taxation, 7, 298-335.

Alpenberg, J., Wnuk-Pel, T., Adamsson, P., \& Petersson, J. (2019). The use of environmental performance indicators in "the greenest city in Europe". Baltic Journal of Management, 14(1), 122-140.

Dobija, D., Górska, A. M., \& Pikos, A. (2019). The impact of accreditation agencies and other powerful stakeholders on the performance measurement in Polish universities. Baltic Journal of Management, 14(1), 84-102.

Bourmistrov, A., Grossi, G., \& Haldma, T. (2019). Special issue on accounting and performance management innovations in public sector organizations. Baltic Journal of Management, 14(1), 7983.

Ferdous, M. I., Adams, C. A., \& Boyce, G. (2019). Institutional drivers of environmental management accounting adoption in public sector water organisations. Accounting, Auditing \& Accountability Journal, $\underline{32(4), 984-101 .}$

Figueira, I., Domingues, A. R., Caeiro, S., Painho, M., Antunes, P., Santos, R., ... \& Ramos, T. B. (2018). Sustainability policies and practices in public sector organisations: The case of the Portuguese Central Public Administration. Journal of Cleaner Production, 202, 616-630.

Domingues, A. R., Lozano, R., Ceulemans, K., \& Ramos, T. B. (2017). Sustainability reporting in public sector organisations: Exploring the relation between the reporting process and organisational change management for sustainability. Journal of Environmental Management, 192, 292-301.

Brinkerhoff, D. W., \& Brinkerhoff, J. M. (2011). Public-private partnerships: Perspectives on purposes, publicness, and good governance. Public Administration and Development, 31(1), 2-14. 
Acs, Z.J., Brooksbank, D.J., O’Gorman, C., Pickernell, D., \& Terjesen, S. (2012). The knowledge spillover theory of entrepreneurship: an application to foreign direct investment. International Journal of Entrepreneurship and Small Business, 15(2), 237-261.

Adams, C.A., Muir, S. and Hoque, Z. (2014). Measurement of sustainability performance in the public sector. Sustainability Accounting, Management and Policy Journal, 5(1), 46-67.

Alcaraz-Quiles, F.J., Navarro-Galera, A., \& Ortiz-Rodríguez, D. (2015). Factors determining online sustainability reporting by local governments. International Review of Administrative Sciences, 81(1), 79-109.

Assaf, A.G., Josiassen, A., Ahn, J.S., \& Mattila, A.S. (2017). Advertising spending, firm performance, and the moderating impact of CSR. Tourism Economics, 23(7), 1484-1495.

Beatty, A., Liao, S., \& Yu, J.J. (2013). The spillover effect of fraudulent financial reporting on peer firms' investments. Journal of Accounting and Economics, 55(2-3), 183-205.

Bellringer, A., Ball, A., \& Craig, R. (2011). Reasons for sustainability reporting by New Zealand local governments. Sustainability Accounting, Management and Policy Journal, 2(1), 126138.

Braam, G.J.M., Uit De Weerd, L., Hauck, M., \& Huijbregts, M.A.J. (2016). Determinants of corporate environmental reporting: the importance of environmental performance and assurance. Journal of Cleaner Production, 129, 724-734.

Branco, M.C., Delgado, C., Gomes, S.F., \& Eugénio, T.C.P. (2014). Factors influencing the assurance of sustainability reports in the context of the economic crisis in Portugal. Managerial Auditing Journal, 29(3), 237-252. 
Brown, S.V., Tian, X.S., \& Tucker, J.W. (2018). The spillover effect of SEC comment letters on qualitative corporate disclosure: evidence from the risk factor disclosure. Contemporary Accounting Research, 35(2), 622-656.

Burritt, R.L., \& Welch, S. (1997a). Accountability for environmental performance of the Australian commonwealth public sector. Accounting, Auditing and Accountability Journal, 10(4), 532-561.

Burritt, R.L., \& Welch, S. (1997b). Australian commonwealth entities: an analysis of their environmental disclosures. Abacus, 33(1), 69-87.

Chabrak, N. (2018). Reforming accounting to support the shift towards a sustainable financial system. Journal of Capital Markets Studies, 2(2), 148-161.

Chiu, T.-K., \& Wang, Y.-H. (2015). Determinants of social disclosure quality in Taiwan: an application of stakeholder theory. Journal of Business Ethics, 129 (2), 379-398.

Cooke, T.E. (1992). The impact of size, stock market listing and industry type on disclosure in the annual reports of Japanese listed corporations. Accounting and Business Research, 22(87), 229-237.

de Souza Cunha, F.A.F, \& Samanez, C.P. (2013). Performance analysis of sustainable investments in the Brazilian stock market: a study about the corporate sustainability index (ISE). Journal of Business Ethics, 117(1), 19-36.

de Villiers, C., \& Marques, A. (2016). Corporate social responsibility, country-level predispositions, and the consequences of choosing a level of disclosure. Accounting and Business Research, 46(2), 167-195.

Domingues, A.R., Lozano, R., Ceulemans, K., \& Ramos, T.B. (2017). Sustainability reporting in public sector organisations: exploring the relation between the reporting process and 
organisational change management for sustainability. Journal of Environmental Management, 192, 292-301.

Dumay, J., Guthrie, J., \& Farneti, F. (2010). GRI sustainability reporting guidelines for public and third sector organizations: a critical review. Public Management Review, 12(4), 531-548.

Ekici, Ş. Ö., Kabak, Ö., \& Ülengin, F. (2016). Linking to compete: Logistics and global competitiveness interaction. Transport Policy, 48, 117-128.

Ertur, C., Le Gallo, J., \& Baumont, C. (2006). The European regional convergence process, 19801995: do spatial regimes and spatial dependence matter? International Regional Science Review, 29(1), 3-34.

Farneti, F., \& Guthrie, J. (2009). Sustainability reporting by Australian public sector organisations: why they report. Accounting Forum, 33(2), 89-98.

Fernandez-Feijoo, B., Romero, S., \& Ruiz, S. (2014). Effect of stakeholders' pressure on transparency of sustainability reports within the GRI framework. Journal of Business Ethics, 122(1), 53-63.

Ferreira, M.A., \& Gama, P.M. (2007). Does sovereign debt ratings news spill over to international stock markets? Journal of Banking and Finance, 31(10), 3162-3182.

Greco, G., Sciulli, N., \& D’Onza, G. (2015). The influence of stakeholder engagement on sustainability reporting: evidence from Italian local councils. Public Management Review, 17(4), 465-488.

Greiling, D., \& Grüb, B. (2014). Sustainability reporting in Austrian and German local public enterprises. Journal of Economic Policy Reform, 17(3), 209-223. 
Greiling, D., Traxler, A.A., \& Stötzer, S. (2015). Sustainability reporting in the Austrian, German and Swiss public sector, International Journal of Public Sector Management, 28(4-5), 404428.

GRI (2015), G4 Sustainability Reporting Guidelines, Global Reporting Initiative. The Netherlands.

GRI SDD. (2017). GRI Sustainability Disclosure Database, available at: http://database.globalreporting.org/ (retrieved on 25-30 November 2017).

Grossi, G., \& Steccolini, I. (2015). Pursuing private or public accountability in the public sector? Applying IPSASs to define the reporting entity in municipal consolidation. International Journal of Public Administration, 38(4), 325-334.

Guenther, E., Guenther, T., Schiemann, F., \& Weber, G. (2016). Stakeholder relevance for reporting: explanatory factors of carbon disclosure. Business and Society, 55(3), 361-397.

Guthrie, J., \& Farneti, F. (2008). GRI sustainability reporting by Australian public sector organizations. Public Money and Management, 28(6), 361-366.

Guthrie, J., Ball, A., \& Farneti, F. (2010). Advancing sustainable management of public and not for profit organizations. Public Management Review, 12(4), 449-459.

Hackston, D., \& Milne, M.J. (1996). Some determinants of social and environmental disclosures in New Zealand companies. Accounting, Auditing and Accountability Journal, 9(1), 77108.

Hahn, R. \& Kühnen, M. (2013). Determinants of sustainability reporting: a review of results, trends, theory, and opportunities in an expanding field of research. Journal of Cleaner Production, 59, 5-21.

Hayes, A.F., 2013. Introduction to Mediation, Moderation, and Conditional Process Analysis: A Regression-based Approach. Guilford Press. 
Ioannou, I., \& Serafeim, G. (2012). What drives corporate social performance? The role of nationlevel institutions. Journal of International Business Studies, 43(9), 834-864.

Joseph, C., \& Taplin, R. (2012). Local government website sustainability reporting: a mimicry perspective. Social Responsibility Journal, 8(3), 363-372.

Kang, E. (2008). Director interlocks and spillover effects of reputational penalties from financial reporting fraud. Academy of Management Journal, 51(3), 537-555.

Kılıç, M., \& Kuzey, C. (2018). Assessing current company reports according to the IIRC integrated reporting framework. Meditari Accountancy Research, 26(2), 305-333.

Kılıç, M., Uyar, A., \& Karaman, A. S. (2019). What impacts sustainability reporting in the global aviation industry? An institutional perspective. Transport Policy, 79, 54-65.

Koppenjan, J.F.M., \& Enserink, B. (2009). Public-private partnerships in urban infrastructures: reconciling private sector participation and sustainability. Public Administration Review, 69(2), 284-296.

Larrinaga-Gonzélez, C., \& Pérez-Chamorro, V. (2008). Sustainability accounting and accountability in public water companies. Public Money and Management, 28(6), 337-343.

Levine, R., \& Zervos, S. (1998). Stock markets, banks, and economic growth. American Economic Review, 88(3), 537-558.

Lewis, T. (2008). Debate: public sector sustainability reporting-implications for accountants. Public Money and Management, 28(6), 329-331.

Liu, X., Lu, J., Filatotchev, I., Buck, T., \& Wright, M. (2010). Returnee entrepreneurs, knowledge spillovers and innovation in high-tech firms in emerging economies. Journal of International Business Studies, 41(7), 1183-1197. 
Lodhia, S., Jacobs, K., \& Park, Y.J. (2012). Driving public sector environmental reporting. Public Management Review, 14(5), 631-647.

López, M. V., Garcia, A., \& Rodriguez, L. (2007). Sustainable development and corporate performance: A study based on the Dow Jones sustainability index. Journal of Business Ethics, 75(3), 285-300.

MacKinnon, D. P., Lockwood, C. M., Hoffman, J.M., West, S. G., \& Sheets, V. (2002). A comparison of methods to test mediation and other intervening variable effects. Psychological Methods, 7, 83-104. doi: 10.1037/1082-989X.7.1.83

Meek, G.K., Roberts, C.B., \& Gray, S.J. (1995). Factors influencing voluntary annual report disclosures by US, UK and continental European multinational corporations. Journal of International Business Studies, 26(3), 555-572.

Menassa, E., \& Brodhäcker, M. (2017). The type and quantity of corporate social disclosures of German 'universal' banks. Journal of Management and Governance, 21(1), 119-143.

Michelon, G., \& Parbonetti, A. (2012). The effect of corporate governance on sustainability disclosure. Journal of Management and Governance, 16(3), 477-509.

Nash, N., Whitmarsh, L., Capstick, S., Hargreaves, T., Poortinga, W., Thomas, G., Sautkina, E., \& Xenias, D. (2017). Climate-relevant behavioral spillover and the potential contribution of social practice theory. Wiley Interdisciplinary Reviews: Climate Change, 8(6), 1-20.

Navarro Galera, A., de los Ríos Berjillos, A., Ruiz Lozano, M., \& Tirado Valencia, P. (2014). Transparency of sustainability information in local governments: English-speaking and Nordic cross-country analysis," Journal of Cleaner Production, 64, 495-504. 
Nilsson, A., Bergquist, M., \& Schultz, W.P. (2017). Spillover effects in environmental behaviors, across time and context: a review and research agenda. Environmental Education Research, 23(4), 573-589.

Oliveira, J., Rodrigues, L.L., \& Craig, R. (2011). Voluntary risk reporting to enhance institutional and organizational legitimacy: evidence from Portuguese banks. Journal of Financial Regulation and Compliance, 19(3), 271-289.

Orsato, R.J., Garcia, A., Mendes-Da-Silva, W., Simonetti, R., \& Monzoni, M. (2015). Sustainability indexes: why join in? A study of the 'corporate sustainability index (ISE)' in Brazil. Journal of Cleaner Production, 96, 161-170.

Pérez-Moreno, S., Rodríguez, B., \& Luque, M. (2016). Assessing global competitiveness under multi-criteria perspective. Economic Modelling, 53, 398-408.

Petera, P., \& Wagner, J. (2017). Human resources disclosure among companies in Czechia. Social Responsibility Journal, 13(4), 743-761.

Pittz, T.G., \& White, R. (2016). Enduring entrepreneurship in the context of public-private partnerships. Journal of Srategic Innovation and Sustainability, 11(1), 38-46.

Preacher, K. J., \& Hayes, A. F. (2008). Asymptotic and resampling strategies for assessing and comparing indirect effects in multiple mediator models. Behavior Research Methods, 40(3), 879-891.

Reid, E.M., \& Toffel, M.W. (2009). Responding to public and private politics: corporate disclosure of climate change strategies. Strategic Management Journal, 30(11), 1157-1178.

Shi, X. (2013). Spillover effects of carbon footprint labelling on less developed countries: the example of the East Asia summit region, Development Policy Review, 31(3), 239-254. 
Singhvi, S.S., \& Desai, H.B. (1971). An empirical analysis of the quality of corporate financial disclosure. The Accounting Review, 46(1), 129-138.

Sirgy, M.J. (2008). Ethics and public policy implications of research on consumer well-being. Journal of Public Policy and Marketing, 27, (2), 207-212.

SSE (2017). Report on progress. available at: https://sseinitiative.org/wpcontent/uploads/2012/03/sse-report-on-progress-2016.pdf (retrieved on 30 November 2017).

SSE (2019). About the SSE. Available at: https://sseinitiative.org/about/about-the-sse/ (retrieved on 14 December 2019).

Thøgersen, J. (1999). Spillover processes in the development of a sustainable consumption pattern. Journal of Economic Psychology, 20(1), 53-81.

Thøgersen, J. (2012). Review of research on the different pathways through which performing one pro-environmental behaviour can influence the likelihood of performing another. BehaviourWorks Australia, available at: https://pdfs.semanticscholar.org/e9f1/b3f089e19a428ec747cdc8312beef96810c4.pdf (retrieved on 7 February 2019).

Thøgersen, J., \& Crompton, T. (2009). Simple and painless? The limitations of spillover in environmental campaigning. Journal of Consumer Policy, 32(2), 141-163.

Umlas, E. (2008). The global expansion of SRI: Facing challenges, meeting potential. Development and Change, 39(6), 1019-1036.

Uyar, A., Kuzey, C., \& Kilic, M. (2019). Testing the Spillover Effects of Sustainability Reporting: Evidence from the Public Sector. International Journal of Public Administration, forthcoming, https://doi.org/10.1080/01900692.2019.1677711. 
Vives, A. (2012). Is socially responsible investment possible in Latin America? Journal of Corporate Citizenship, (48), 59-74.

Wang, C.C., \& Wu, A. (2016). Geographical FDI knowledge spillover and innovation of indigenous firms in China. International Business Review, 25(4), 895-906.

Wang, Y., \& Liu, L. (2016). Spillover effect in Asian financial markets: a VAR-structural GARCH analysis. China Finance Review International, 6(2), 150-176.

WEF (2016). The global competitiveness report 2015-2016. available at: http://www3.weforum.org/docs/gcr/2015-2016/Global_Competitiveness_Report_20152016.pdf (retrieved on 10 February 2019).

WorldBank (2017). World Bank Open Data. available at: http://databank.worldbank.org/data/home.aspx (accessed 20-25 December 2017).

Yadava, R.N., \& Sinha, B. (2016). Scoring sustainability reports using GRI 2011 guidelines for assessing environmental, economic, and social dimensions of leading public and private Indian companies. Journal of Business Ethics, 138(3), 549-558.

Zhao, X., Lynch, J. G., \& Chen, Q. (2010). Reconsidering Baron and Kenny: Myths and Truths about Mediation Analysis. Journal of Consumer Research, 37(2), 197-206. http://doi.org/10.1086/651257

Draper, N., and H. Smith. (1998). Applied Regression Analysis. 3rd ed. New York: Wiley.

Wooldridge, J. M. (2013). Introductory Econometrics: A Modern Approach. 5th ed. Mason, OH: South-Western.

Davidson, R., \& MacKinnon, J. G. (2004). Econometric theory and methods (Vol. 5). New York: Oxford University Press. 
Shrout, P. E., \& Bolger, N. (2002). Mediation in experimental and nonexperimental studies: new procedures and recommendations. Psychological methods, 7(4), 422.

Baron, R. M., \& Kenny, D. A. (1986). The moderator-mediator variable distinction in social psychological research: Conceptual, strategic, and statistical considerations. Journal of Personality and Social Psychology, 5, 1173-1182. 
Table 1. The list of variables used in the study

\begin{tabular}{llc}
\hline Variables & Measurement & Source \\
\hline \multicolumn{2}{l}{ Independent variable: } & SSE (2017) \\
SustIndex & 1 if the stock market has sustainability index, and 0 otherwise & \\
Dependent variables: & GRI SDD (2017) \\
PubSecReport $\quad$ Public Sector's number of sustainability reports (overall) & GRI SDD (2017) \\
PubSecGRI & Public Sector's number of GRI-based sustainability reports & GRI SDD (2017) \\
Mediating variables: & GRI SDD (2017) \\
PrivSecReport & Private Sector's number of sustainability reports (overall) & \\
PrivSecGRI & Private Sector's number of GRI-based sustainability reports & WorldBank (2017) \\
Control variables: & WorldBank (2017) \\
ExportRatio & Percentage of goods and services exported relative to GDP & WorldBank (2017) \\
GDP & The natural logarithm of GDP (current US\$) & WEF (2016) \\
MarketCapt & Market capitalization of listed domestic companies (\% of the GDP) \\
EquitMarkt & Financing through local equity market ranged between 1 and 7 (strong) \\
RuleLaw & Rule of law score of countries ranging between -2.5 and 2.5 & WorldBank (2017) \\
GovernExp & The percentage of the general government expenditure relative to GDP & WorldBank (2017) \\
Population & Total population's natural logarithm & WorldBank (2017) \\
\hline
\end{tabular}

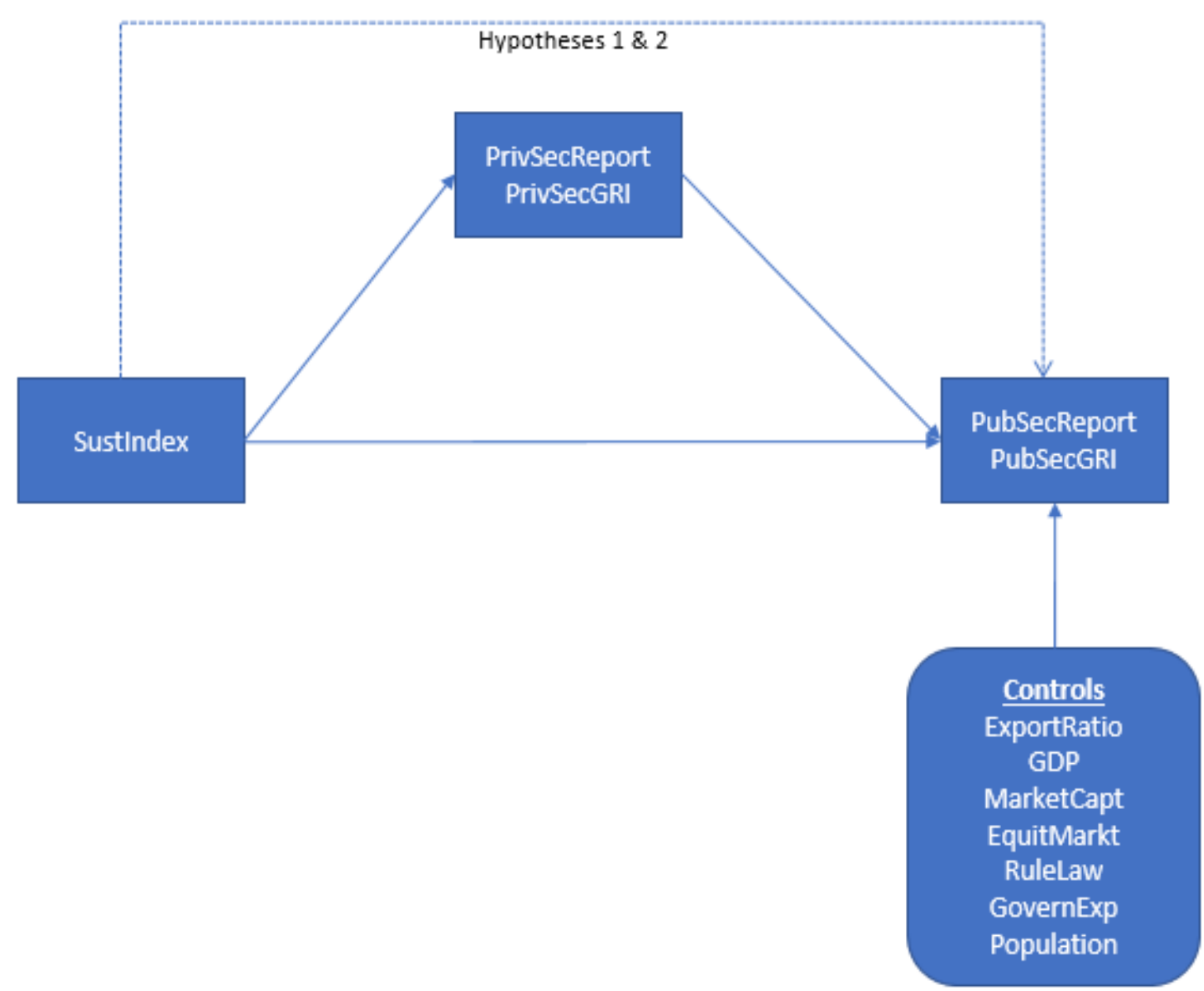

Figure 1. The indirect effect of SustIndex on PubSecReport/PubSecGRI via PrivSecReport/PrivSecGRI. The mediation analysis was performed separately with the two mediators and two dependent variables. 
Table 2. Descriptive Statistics

\begin{tabular}{|c|c|c|c|c|c|c|}
\hline Variables & & $\mathbf{N}$ & Min & Max & Mean & S.D. \\
\hline PubSecReport & & 115 & 0.00 & 84.00 & 9.40 & 18.57 \\
\hline PubSecGRI & & 115 & 0.00 & 74.00 & 7.43 & 15.85 \\
\hline PrivSecReport & & 115 & 0.00 & 3778.00 & 517.55 & 728.26 \\
\hline PrivSecGRI & & 115 & 0.00 & 2664.00 & 406.51 & 550.64 \\
\hline ExportRatio & & 115 & 10.35 & 222.70 & 51.65 & 44.33 \\
\hline GDP & & 115 & 23.05 & 30.56 & 26.50 & 1.55 \\
\hline MarketCapt & & 115 & 9.60 & 1029.36 & 79.99 & 135.23 \\
\hline EquitMarkt & & 115 & 2.12 & 5.94 & 4.19 & 0.88 \\
\hline RuleLaw & & 115 & -0.96 & 2.04 & 0.59 & 0.91 \\
\hline GovernExp & & 115 & 6.33 & 30.00 & 16.41 & 4.91 \\
\hline Population & & 115 & 13.01 & 21.04 & 16.89 & 1.72 \\
\hline \multirow[t]{4}{*}{ SustIndex } & Categories & & & Frequency & & Percent \\
\hline & Exist & & & 54 & & 47.00 \\
\hline & Doesn't Exist & & & 61 & & 53.00 \\
\hline & Total & & & 115 & & 100.00 \\
\hline
\end{tabular}

Table 3. Pearson's Correlation analysis

\begin{tabular}{|c|c|c|c|c|c|c|c|}
\hline & Variables & V1 & $\mathbf{V 2}$ & $\mathbf{V 3}$ & V4 & V5 & V6 \\
\hline 1 & PubSecReport & 1 & & & & & \\
\hline 2 & PubSecGRI & $.964 * *$ & 1 & & & & \\
\hline 3 & PrivSecReport & $.504 * *$ & $.445 * *$ & 1 & & & \\
\hline 4 & PrivSecGRI & $.552 * *$ & $.506 * *$ & $.983 * *$ & 1 & & \\
\hline 5 & ExportRatio & -0.069 & -0.057 & $-.280 * *$ & $-.286 * *$ & 1 & \\
\hline 6 & GDP & $.430 * *$ & $.390 * *$ & $.713 * *$ & $.730 * *$ & $-.338 * *$ & 1 \\
\hline 7 & MarketCapt & 0.125 & 0.129 & 0.151 & 0.119 & $.464 * *$ & 0.109 \\
\hline 8 & EquitMarkt & $.186^{*}$ & 0.137 & $.326 * *$ & $.267 * *$ & $.239 * *$ & $.286 * *$ \\
\hline 9 & RuleLaw & $.375 * *$ & $.322 * *$ & $.246 * *$ & $.253 * *$ & $.443 * *$ & 0.129 \\
\hline 10 & GovernExp & 0.078 & 0.072 & 0.169 & 0.167 & -0.111 & 0.073 \\
\hline 11 & Population & 0.14 & 0.135 & $.491 * *$ & $.498 * *$ & $-.567 * *$ & $.787 * *$ \\
\hline \multirow[t]{2}{*}{12} & SustIndex & $.189 *$ & $.194 *$ & $.484 * *$ & $.507 * *$ & -0.056 & $.496 * *$ \\
\hline & Variables & V7 & V8 & V9 & V10 & V11 & V12 \\
\hline 7 & MarketCapt & 1 & & & & & \\
\hline 8 & EquitMarkt & $.463 * *$ & 1 & & & & \\
\hline 9 & RuleLaw & $.319 * *$ & $.567 * *$ & 1 & & & \\
\hline 10 & GovernExp & -0.134 & 0.083 & $.338 * *$ & 1 & $-.196 *$ & 0.007 \\
\hline 11 & Population & -0.057 & -0.001 & $-.416 * *$ & $-.196 *$ & 1 & \\
\hline 12 & SustIndex & 0.042 & $.281 * *$ & $.263 * *$ & 0.007 & $.352 * *$ & 1 \\
\hline
\end{tabular}


Table 4. Regression analysis results

\begin{tabular}{|c|c|c|c|c|}
\hline $\begin{array}{l}\text { Independent } \\
\text { Variables }\end{array}$ & $\begin{array}{r}\text { (1) } \\
\text { PubSecReport }\end{array}$ & $\begin{array}{r}\text { (2) } \\
\text { PrivSecReport }\end{array}$ & $\begin{array}{r}\text { (3) } \\
\text { PubSecGRI }\end{array}$ & $\begin{array}{r}(4) \\
\text { PrivSecGRI }\end{array}$ \\
\hline SustIndex & $\begin{array}{r}-3.49 \\
(-0.88)\end{array}$ & $\begin{array}{r}252.8^{* * *} \\
(2.50)\end{array}$ & $\begin{array}{r}-1.21 \\
(-0.38)\end{array}$ & $\begin{array}{r}213.9 * * * \\
(3.09)\end{array}$ \\
\hline ExportRatio & $\begin{array}{r}-0.10 * * \\
(-2.56)\end{array}$ & $\begin{array}{r}-4.11 * * * \\
(-3.24)\end{array}$ & $\begin{array}{r}-0.075^{* *} \\
(-2.39)\end{array}$ & $\begin{array}{r}-3.03 * * * \\
(-3.47)\end{array}$ \\
\hline GDP & $\begin{array}{r}8.38 * * * * \\
(4.32)\end{array}$ & $\begin{array}{r}273.0^{* * * *} \\
(3.31)\end{array}$ & $\begin{array}{r}6.50 * * * \\
(3.72)\end{array}$ & $\begin{array}{r}221.5^{* * * *} \\
(4.08)\end{array}$ \\
\hline MarketCapt & $\begin{array}{r}0.0099 \\
(1.33)\end{array}$ & $\begin{array}{r}0.79 * * \\
(2.00)\end{array}$ & $\begin{array}{r}0.013 * \\
(1.94)\end{array}$ & $\begin{array}{r}0.54 * * \\
(2.42)\end{array}$ \\
\hline EquitMarkt & $\begin{array}{r}-3.61 \\
(-1.61)\end{array}$ & $\begin{array}{r}33.4 \\
(0.46)\end{array}$ & $\begin{array}{l}-3.74 * \\
(-1.74)\end{array}$ & $\begin{array}{r}-39.8 \\
(-0.83)\end{array}$ \\
\hline RuleLaw & $\begin{array}{r}8.07 * * * * \\
(2.88)\end{array}$ & $\begin{array}{r}82.5 \\
(0.90)\end{array}$ & $\begin{array}{r}5.69 * * \\
(2.55)\end{array}$ & $\begin{array}{r}98.4 \\
(1.65)\end{array}$ \\
\hline GovernExp & $\begin{array}{r}-0.69 * * * \\
(-2.64)\end{array}$ & $\begin{array}{r}8.78 \\
(0.70)\end{array}$ & $\begin{array}{l}-0.47^{*} \\
(-1.98)\end{array}$ & $\begin{array}{r}4.32 \\
(0.54)\end{array}$ \\
\hline Population & $\begin{array}{r}-4.10 * * * \\
(-2.72)\end{array}$ & $\begin{array}{r}-44.4 \\
(-0.70)\end{array}$ & $\begin{array}{r}-3.28 * * \\
(-2.24)\end{array}$ & $\begin{array}{r}-36.8 \\
(-0.83)\end{array}$ \\
\hline Constant & $\begin{array}{r}-115.5^{* * * *} \\
(-4.08)\end{array}$ & $\begin{array}{r}-6269.4 * * * \\
(-5.04) \\
\end{array}$ & $\begin{array}{r}-86.2 * * * \\
(-3.75)\end{array}$ & $\begin{array}{r}-4789.9 * * * \\
(-5.86)\end{array}$ \\
\hline $\begin{array}{l}\mathrm{N} \\
\text { Adi. } \mathrm{R}^{2}\end{array}$ & $\begin{array}{r}115 \\
0.307\end{array}$ & $\begin{array}{r}115 \\
0.555\end{array}$ & $\begin{array}{r}115 \\
0.230\end{array}$ & $\begin{array}{r}115 \\
0.582\end{array}$ \\
\hline F-Statistics & $5.93^{* * * *}$ & $9.79 * * *$ & 6.36 *** & $10.22 * * *$ \\
\hline
\end{tabular}

Table 5. Mediation analysis outputs

\begin{tabular}{lrrrrrrrr}
\hline Hypothesis & \multicolumn{3}{c}{ Direct effect } & \multicolumn{4}{c}{ Indirect effect } & \multirow{2}{*}{ Result } \\
\cline { 2 - 7 } & Effect & LLCI & ULCI & Effect & LLCI & ULCI & \\
\hline H1) SustIndex $\rightarrow$ PrivSecReport $\rightarrow$ PubSecReport & -5.830 & -12.815 & 0.155 & $2.344^{*}$ & 0.306 & 7.275 & Full mediation \\
& & & & & & & \\
H2) SustIndex $\rightarrow$ PrivSecGRI $\rightarrow$ PubSecGRI & -3.801 & -10.099 & 2.496 & $2.594 *$ & 0.496 & 7.691 & Full mediation \\
\hline
\end{tabular}

Note 1: *Indicates significant indirect effect since the corresponding lower limit and upper limit does not include zero;

Note 2: Control variables: ExportRatio, GDP, MarketCapt, EquitMarkt, RuleLaw, GovernExp, Population Note 3: LLCI: Lower Limit Confidence Interval; ULCI: Upper Limit Confidence Interval 


\section{Notes}

${ }^{1}$ Please see Hahn and Kühnen (2013) for an extensive review of the literature on the drivers of sustainability reporting.

2 GRI is a not-for-profit worldwide organization and has a global recognition by the public and private firms/organizations (Siew, 2015). It issues overall and sector-specific (including the public sector) sustainability reporting guidelines. Its report disclosure database enables organizations to upload their sustainability reports prepared by either with or without a specific reference to GRI frameworks.

${ }^{3}$ Please see other single-country studies (Guthrie \& Farneti, 2008; Larrinaga-Gonzélez \& Pérez-Chamorro, 2008; Farneti \& Guthrie, 2009; Joseph \& Taplin, 2012; Lodhia et al., 2012).

${ }^{4}$ Indeed, the cited two studies (Greiling \& Grüb, 2014; Greiling, Traxler, \& Stötzer, 2015) are not based on completely international sample; they studied Austrian, German and Swiss public sector organizations. Navarro Galera et al. (2014)'s study is based on a questionnaire survey, and their analyses are descriptive rather than multivariate analysis. Domingues et al. (2017) examined the sustainability reporting tendency of European local governments. Uyar et al. (2019)'s empirical study is based on a completely international sample.

${ }^{5}$ Throughout the text, the phrase "sustainable stock market" is used for the stock markets which have already established a specific sustainability index.

${ }^{6}$ There are good examples of how government intervention into sustainability issues as a regulatory force yield positive outcomes (Ferdous et al., 2019).

${ }^{7}$ The public sector can benefit from GRI guidelines' materials usage, energy efficiency, waste management, and recycling metrics in developing an environmentally-friendly service provision (GRI, 2015).

${ }^{8}$ Like Bourmistrov et al. (2019) pointed out in their study. 